\title{
Review Article \\ Genetic Variants in SNCA and the Risk of Sporadic Parkinson's Disease and Clinical Outcomes: A Review
}

\author{
Clarissa Loureiro das Chagas Campêlo ${ }^{1}$ and Regina Helena Silva ${ }^{2}$ \\ ${ }^{1}$ Memory Studies Laboratory, Department of Physiology, Universidade Federal do Rio Grande do Norte, Natal, RN, Brazil \\ ${ }^{2}$ Behavioral Neuroscience Laboratory, Department of Pharmacology, Universidade Federal de São Paulo, São Paulo, SP, Brazil \\ Correspondence should be addressed to Regina Helena Silva; reginahsilva@gmail.com
}

Received 13 January 2017; Revised 17 April 2017; Accepted 24 May 2017; Published 11 July 2017

Academic Editor: Hao Deng

Copyright (C) 2017 Clarissa Loureiro das Chagas Campêlo and Regina Helena Silva. This is an open access article distributed under the Creative Commons Attribution License, which permits unrestricted use, distribution, and reproduction in any medium, provided the original work is properly cited.

\begin{abstract}
There is increasing evidence of the contribution of genetic susceptibility to the etiology of Parkinson's disease (PD). Genetic variations in the SNCA gene are well established by linkage and genome-wide association studies. Positive associations of single nucleotide polymorphisms (SNPs) in SNCA and increased risk for PD were found. However, the role of SNCA variants in individual traits or phenotypes of PD is unknown. Here, we reviewed the current literature and identified 57 studies, performed in fourteen different countries, that investigated SNCA variants and susceptibility to PD. We discussed the findings based on environmental factors, history of PD, clinical outcomes, and ethnicity. In conclusion, SNPs within the SNCA gene can modify the susceptibility to PD, leading to increased or decreased risk. The risk associations of some SNPs varied among samples. Of notice, no studies in South American or African populations were found. There is little information about the effects of these variants on particular clinical aspects of PD, such as motor and nonmotor symptoms. Similarly, evidence of possible interactions between SNCA SNPs and environmental factors or disease progression is scarce. There is a need to expand the clinical applicability of these data as well as to investigate the role of SNCA SNPs in populations with different ethnic backgrounds.
\end{abstract}

\section{Introduction}

Parkinson's disease (PD) is a neurodegenerative disorder that is characterized by motor dysfunction but also causes nonmotor deficits [1]. Although the etiology of PD remains unclear, the interaction between genetic and environmental factors has been implicated in the emergence of the disease [ 2 , 3]. Genome-wide association studies (GWAS) have identified variants of many candidate genes that contribute to $\mathrm{PD}$ susceptibility, such as variations of the SNCA gene [4-6]. Moreover, certain polymorphisms of SNCA are among the major risk factors for sporadic PD [5].

The SNCA gene is located on human chromosome 4 and encodes the protein alpha-synuclein. The physiological function of alpha-synuclein is not completely understood. Studies have shown a key role for alpha-synuclein in the regulation of neurotransmitter release, synaptic function, and plasticity of dopaminergic neurons [7-9]. The involvement in dopaminergic transmission and the predominant presence of alpha-synuclein in Lewy bodies [10-12] denote the relationship of this protein with the etiology of PD. In addition, genetic data support the role of alpha-synuclein in the pathogenic process of the disease. For example, missense mutations in SNCA locus were identified in familial forms of PD (A53T, A30P, E46K, and H50Q) [13-17], as well as in sporadic PD patients (A18T and A29S) [18]. Further, duplications and triplications of the SNCA locus cause familial parkinsonism and correlate with disease severity $[19,20]$.

Single nucleotide polymorphism (SNP) analyses in casecontrol studies performed in different populations have shown an association between several SNCA polymorphisms and the risk of PD. For example, the dinucleotide repeat REP1 located in the SNCA promoter (SNCA-REP1) and the $3^{\prime}$ untranslated region (UTR) variants are frequently investigated [21]. Variations in these regions may increase susceptibility to PD by interfering with transcription factor binding sites $[22,23]$ and creating or destroying microRNAs target sites, which in turn modifies gene expression [24-26]. 
In spite of the fact that this type of study is frequent, investigations of the association between SNPs and the risk of PD in different populations show conflicting results. Furthermore, the consequences of genetic variability on clinical phenotypes, as well the interaction between genetic and environmental substrates, are poorly elucidated. Ideally, data from SNP studies would improve knowledge of pathophysiological pathways and help to target the best therapeutic program. This review aims to identify and compare the main SNP association studies conducted in different populations. The role of SNCA polymorphisms as a risk factor for PD and their association with clinical outcomes are discussed.

\section{Literature Search}

We conducted a survey in the relevant databases PubMed/ Medline and Scopus for studies up to July 2016 using combinations of the keywords "polymorphism", "alpha synuclein", "SNCA gene", and "Parkinson's disease". We selected articles that met the following inclusion criteria: (a) articles that are written in English; (b) articles that described investigations of SNPs in the SNCA gene; (c) articles that had available data of allele and genotype distributions; (d) studies that were conducted in humans; (e) studies including participants who were diagnosed with Parkinson's disease. 57 studies were selected to conduct the review. In addition, despite not necessarily meeting the selection criteria, other relevant publications were included throughout the article in order to foment discussion.

The following information was extracted from each study: authors, year of publication, country of the studied population, number of patients and control subjects, risk association with $\mathrm{PD}$, and investigation of environmental factors and clinical outcomes. The association of SNCA polymorphisms and PD susceptibility was often assessed by comparing the frequency of risk allele and risk genotypes in patients and controls. Values of odds ratio (OR) and confidence interval (95\% CI) indicated the characteristic and significance of the association (OR values higher than 1 indicated increased risk and values lower than 1 suggested reduced risk).

Table 1 summarizes the main data from the 57 selected studies. The majority of the studies were performed in Caucasian and Asian populations. The studies were carried out in fourteen different countries (Mexico, China, Russia, Germany, Taiwan, USA, Japan, Spain, Italy, Ireland, Netherlands, Norway, Australia, and Greece) assembling patients from twenty countries (Mexico, China, Russia, Germany, Taiwan, USA, Japan, Spain, Italy, Norway, Netherlands, Serbia, Ireland, Australia, France, Greece, Poland, Sweden, Iran, and Australia). Sample sizes varied from 91 to 5302 patients in PD groups. The mean age at onset of PD varied from 45.2 to 68.2 years old.

\section{SNPs and the Risk for Parkinson's Disease}

GWAS have identified 28 distinct loci that modify the individual risk to PD [85] and suggest that genetic factors contribute to at least one-fourth of the total variation in liability to PD [86]. The two most consistent genes for susceptibility to sporadic PD are the alpha-synuclein (SNCA) and microtubule-associated protein tau (MAPT) genes, which can exert independent or joint effects on the risk of PD [56, $59,61,62,87]$. In addition, variants in other genes previously linked with autosomal forms (LRRK2, PARK16-18, and GBA) have also shown association with PD risk [64, 88-90]. Based on odds ratio and confidence intervals values in the selected studies, thirty-nine different SNPs in the SNCA gene showed a statistically significant effect on PD susceptibility: nine variants in the $5^{\prime}$ end, nine variants near the $3^{\prime}$ end, and 25 intron variants (Table 2 ). The locations of the six more frequently investigated SNPs within the SNCA gene are illustrated in Figure 1.

Two major linkage disequilibrium blocks in the SNCA gene have been proposed: (1) a $5^{\prime}$ block that extends from the promoter-enhancer region to exon 4 and (2) a $3^{\prime}$ block that includes intron $4,3^{\prime}$ UTR, and the $3^{\prime}$ end region of the gene $[73,80]$. SNPs in the $3^{\prime}$ block presented a more expressive association with PD. The largest number of significant markers in the $3^{\prime}$ block across different populations suggests a major causal effect for variants located in the $3^{\prime}$ end compared with the $5^{\prime}$ end. The $3^{\prime}$ block contains elements with higher conservation across species, which emphasize its biological relevance [25].

The polymorphic microsatellite REP1 (D4S3481) in the promoter region of SNCA is one of the most frequently investigated polymorphisms and was pointed out as a risk factor in thirteen of the articles $[47,50,60,64,65,68$, $71-73,75,77,79,81]$. REP1 region plays a crucial role in the regulation of alpha-synuclein protein expression. Variants in REP1 are the only putative functional polymorphism identified within the SNCA locus. The REP1 SNP is a triallelic polymorphism with the longest (263 bp) and intermediate length (261 bp) alleles usually associated with an increased risk for PD, as seen in studies with North American [47, 50, 60, 64, 65, 68, 71, 72, 75, 81], German [73], Greek [79], and Dutch [77] samples. In 2006, a meta-analysis including over 5000 subjects provided strong evidence that the $263 \mathrm{bp}$ allele was more frequent in cases and that the $259 \mathrm{bp}$ allele was more frequent in controls (indicating decreased risk of PD) [91]. The other four SNPs in the $5^{\prime}$ region (rs2619362, rs2619363, rs2619364, and rs2583988) contributed to the increase in the risk of PD in North American [49, 65] and European [56, 61, 77] populations.

Twenty-five intronic variants were associated with $\mathrm{PD}$ susceptibility, although the precise function of those variants of human SNCA is still unknown. The SNP rs2736990 in intron 4 was the most frequent, with the exception of one study [40]; this SNP was a consistent risk factor for PD [27, 28, 41, 49, 52, 55]. Similarly, the SNPs rs2572324, rs7684318, and rs894278 also increased susceptibility to sporadic PD $[49,60,64,65]$. In contrast, a significant reduction of PD risk was found for the SNP rs356186 in Italian [56], North American [60], and Irish [61] samples.

Recently, the SNPs located near the $3^{\prime}$ end have also been identified as risk factors for PD. Within the $3^{\prime}$ region, the majority of the studies focused on rs356219, rs11931074, and rs356165. Among them, the SNP rs356219 was the most 
TABLE 1: Characterization of the reviewed studies.

\begin{tabular}{|c|c|c|c|c|c|}
\hline \multirow{2}{*}{ Studies } & \multirow{2}{*}{ Study ID } & \multirow{2}{*}{ Country of participants } & \multicolumn{2}{|c|}{ Sample size } & \multirow{2}{*}{$\begin{array}{c}\text { Onset age } \\
(\text { mean } \pm \mathrm{SD})\end{array}$} \\
\hline & & & $\mathrm{PD}$ & Ctr & \\
\hline Davila-Ortiz de Montellano et al., 2016 & {$[27]$} & Mexico & 171 & 171 & - \\
\hline Davis et al., 2016 & {$[28]$} & USA & 418 & 150 & $60.4 \pm 11.1$ \\
\hline García et al., 2016 & [29] & Mexico & 106 & 135 & $56.2 \pm 14.4$ \\
\hline Shahmohammadibeni et al., 2016 & {$[30]$} & Iran & 489 & 489 & - \\
\hline Wang et al., 2016 & {$[31]$} & China & 296 & - & - \\
\hline Cheng et al., 2016 & {$[32]$} & China & 1053 & 1152 & $52.0 \pm 10.4$ \\
\hline Guella et al., 2016 & {$[33]$} & Multicentric ${ }^{*}$ & 1492 & 971 & $60.3 \pm 10.2$ \\
\hline Chen et al., 2015 & {$[34]$} & China & 218 & 110 & $60.6 \pm 07.4$ \\
\hline Huang et al., 2015 & {$[35]$} & China, Australia & 402 & - & - \\
\hline Han et al., 2015 & {$[36]$} & China & 91 & 92 & - \\
\hline Chen et al., 2015 & {$[37]$} & China & 1276 & 846 & $56.3 \pm 11.5$ \\
\hline Gao et al., 2015 & {$[38]$} & USA & 507 & 1330 & $68.3 \pm 5.8$ \\
\hline Cardo et al., 2014 & [39] & China & 752 & 489 & - \\
\hline Guo et al., 2014 & {$[40]$} & China & 1011 & 721 & $56.6 \pm 11.8$ \\
\hline Pan et al., 2013 & {$[41]$} & China & 515 & 450 & $45.2 \pm 04.6$ \\
\hline Mata et al., 2014 & {$[42]$} & USA & 1191 & - & $59.46 \pm 10.6$ \\
\hline Markopoulou et al., 2014 & {$[43]$} & USA & 1098 & - & 62.2 \\
\hline Emelyanov et al., 2013 & {$[44]$} & Russia & 244 & 308 & - \\
\hline Wu-Chou et al., 2013 & {$[45]$} & Taiwan & 626 & 473 & $63.2 \pm 07.8$ \\
\hline Brockmann et al., 2013 & {$[46]$} & Germany & 1396 & - & $56.9 \pm 01.9$ \\
\hline Chung et al., 2013 & {$[47]$} & USA & 1098 & 1098 & 60.4 \\
\hline Pihlstrøm et al., 2013 & {$[48]$} & Norway and Sweden & 1380 & 1295 & 59.0 \\
\hline Heckman et al., 2012 & [49] & USA & 426 & 769 & $62.0 \pm 12.0$ \\
\hline Ritz et al., 2012 & {$[50]$} & USA & 232 & - & - \\
\hline Schmitt et al., 2012 & {$[51]$} & Germany & 980 & 1005 & $59.4 \pm 12.2$ \\
\hline Miyake et al., 2012 & {$[52]$} & Japan & 229 & 357 & $65.7 \pm 08.8$ \\
\hline Pan et al., 2012 & {$[53]$} & China & 403 & 315 & $57.8 \pm 08.6$ \\
\hline Cardo et al., 2012 & {$[54]$} & Spain & 727 & 480 & - \\
\hline Gao et al., 2012 & {$[55]$} & USA & 584 & 1571 & $68.2 \pm 05.7$ \\
\hline Trotta et al., 2012 & {$[56]$} & Italy & 904 & 891 & $56.1 \pm 11.0$ \\
\hline Hu et al., 2012 & {$[57]$} & China & 110 & 136 & $56.7 \pm 10.8$ \\
\hline Botta-Orfilla et al., 2012 & {$[58]$} & Spain & 84 & - & - \\
\hline Mata et al., 2011 & {$[59]$} & Spain & 1445 & 1161 & $60.0 \pm 12.2$ \\
\hline Chung et al., 2011 & {$[60]$} & USA & 1103 & 1103 & 62.2 \\
\hline Elbaz et al., 2011 & {$[61]$} & Multicentric ${ }^{* *}$ & 5302 & 4161 & - \\
\hline Wider er al., 2011 & {$[62]$} & USA, Ireland, Norway & 1020 & 1095 & $58.0 \pm 12.0$ \\
\hline Botta-Orfilla et al., 2011 & {$[63]$} & Spain & 757 & 708 & - \\
\hline Biernacka et al., 2011 & {$[64]$} & USA & 1098 & 1098 & 62.2 \\
\hline Mata et al., 2010 & {$[65]$} & USA & 1956 & 2112 & $58.7 \pm 11.9$ \\
\hline Yu et al., 2010 & {$[66]$} & China & 332 & 300 & $54.3 \pm 11.1$ \\
\hline Hu et al., 2010 & {$[67]$} & China & 330 & 300 & $52.6 \pm 11.8$ \\
\hline Gatto et al., 2010 & {$[68]$} & USA & 333 & 336 & - \\
\hline Rajput et al., 2009 & [69] & Canada & 452 & 245 & - \\
\hline Sutherland et al., 2009 & {$[70]$} & Australia & 331 & 296 & $60.1 \pm 10.6$ \\
\hline Brighina et al., 2009 & {$[71]$} & USA & 893 & 893 & 62.1 \\
\hline Kay et al., 2008 & {$[72]$} & USA & 1802 & 2192 & - \\
\hline Myhre et al., 2008 & {$[73]$} & Netherlands & 236 & 236 & - \\
\hline Verbaan et al., 2008 & {$[74]$} & Netherlands & 295 & 150 & - \\
\hline Brighina et al., 2008 & {$[75]$} & USA & 833 & 833 & 61.9 \\
\hline Ross et al., 2007 & {$[76]$} & Ireland & 186 & 186 & $50.0 \pm 11.0$ \\
\hline Winkler et al., 2007 & {$[77]$} & Germany, Serbia & 397 & 270 & - \\
\hline
\end{tabular}


TABLE 1: Continued.

\begin{tabular}{|c|c|c|c|c|c|}
\hline \multirow{2}{*}{ Studies } & \multirow{2}{*}{ Study ID } & \multirow{2}{*}{ Country of participants } & \multicolumn{2}{|c|}{ Sample size } & \multirow{2}{*}{$\begin{array}{c}\text { Onset age } \\
(\text { mean } \pm \mathrm{SD})\end{array}$} \\
\hline & & & $\mathrm{PD}$ & Ctr & \\
\hline Goris et al., 2007 & {$[78]$} & UK & 659 & 2176 & 63.0 \\
\hline Hadjigeorgiou et al., 2006 & [79] & Greece & 178 & 186 & $63.3 \pm 9.6$ \\
\hline Mueller et al., 2005 & {$[80]$} & Germany & 669 & 1002 & $55.4 \pm 19.1$ \\
\hline Mamah et al., 2005 & {$[81]$} & USA & 557 & 557 & 63.0 \\
\hline Spadafora et al., 2003 & {$[82]$} & Italy & 186 & 182 & - \\
\hline Izumi et al., 2001 & {$[83]$} & Japan & 200 & 250 & $61.0 \pm 09.1$ \\
\hline
\end{tabular}

ID: identification; PD: Parkinson's disease group; Ctr: control group; SD: standard deviation. ${ }^{*}$ The countries of origin of participants were New Zeeland, Canada, UK, and USA. ${ }^{* *}$ The countries of origin of participants were Australia, France, Germany, Greece, Ireland, Italy, Norway, Poland, Sweden, and USA.

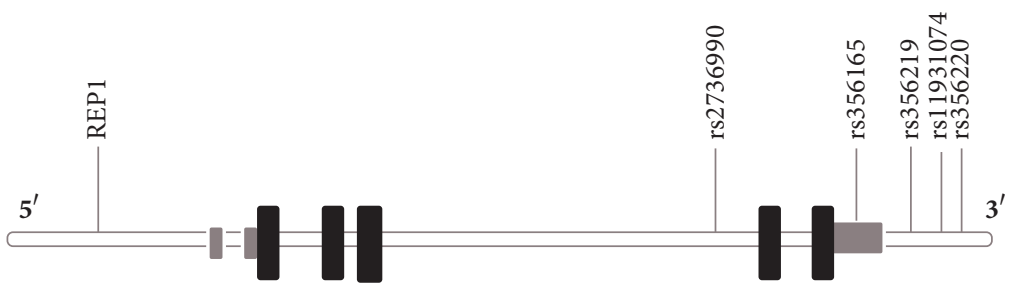

FIgURE 1: Diagram illustrating the locations of the main SNPs in human SNCA gene reviewed in the present study: SNCA-REP1 (promoter region), rs2736990 (intron 4), rs356165 ( $3^{\prime}$ UTR), and rs356219, rs356220, and rs11931074 (3' end). Black boxes indicate translated exons, grey boxes indicate untranslated regions, and the white line indicates introns.

investigated, and it stands out as a consistent risk factor for $\mathrm{PD}$ in twelve of the studies. Variants in the $3^{\prime}$ region possibly increase SNCA expression because of the misregulation of the posttranscriptional control. In the $3^{\prime}$ untranslated region (UTR), there are target binding sites for two microRNAs (mir-7 and mir-153), and alterations in these regions might affect mRNA stability and translation [92]. Further, mir-7 and mir-153 were associated with SNCA mRNA expression in human studies $[23,24]$. The SNP rs356219 showed a robust association as a common susceptibility marker in twelve studies with patients from Russia [44], Germany [46, 80], Spain [58, 59], Japan [52], China [53], USA [28, 65], United Kingdom [78], and Netherlands [73]. Similarly, the SNP rs11931074 showed a significant association with increased PD risk in seven studies, four of which were performed in Chinese samples [32, 34, 39, 40].

The variants rs356221, rs356165, and rs356182 in $3^{\prime}$ UTR also contribute significantly to the increase in the PD risk in Germany [51, 77, 80], USA [28, 50], China [34], Taiwan [45], and Netherlands [73]. These findings reinforce the role of a posttranscriptional mechanism in PD etiology. The variant rs356165 was the most expressive $[28,50,51,54,61,73,77,80]$.

\section{SNCA SNPs and Environmental Factors Interactions}

Despite the relevance of environmental data to the understanding of the etiology of PD, the majority of studies contain little or no information on possible associations between SNCA SNPs and environmental factors (Table 3).

Sporadic PD is considered a result of complex interactions between genetic and environmental risk factors.
Professional pesticide exposure, rural living, and well-water drinking were reported to increase the risk of PD [93-95]. In contrast, cigarette smoking $[96,97]$ and caffeine intake [98] have been pointed out as protective factors. Furthermore, though less consistently, reduced PD risk was associated with alcohol drinking [99]. Potential interactions between SNCA SNPs and pesticide exposure, smoking habits, head injury, or coffee and alcohol drinking were investigated in a few of the studies $[47,50,52,55,56]$. Overall, data demonstrated some pairwise interactions, but without reaching significant levels after Bonferroni correction. For example, although Miyake et al. [52], Chung et al. [47], and Gao et al. [55] found a significant protective effect of smoking habits against PD, corroborating epidemiological data, only the first study found significant interactions between SNPs rs356219 and rs356220 and smoking.

Meta-analyses $[96,97]$ have reinforced the inverse association between cigarette smoking and PD risk more consistently than other environmental factors (rural living, wellwater consumption, farming, and the use of pesticides). One of the mechanisms suggested to underlie this neuroprotection is the reduction of brain levels of the enzyme monoamine oxidase B (MAO B), an isoform that selectively metabolizes dopamine. This reduction would enhance the levels of dopamine and decrease the production of hydrogen peroxide and oxidative stress rates [100]. An alternative explanation is that smoke induces cytochrome P-450 enzyme activity. This enzyme is responsible for the metabolism of antipsychotic drugs and the detoxification of certain environmental toxins such as MPTP [101]. In this respect, a case-control study carried out in European countries investigated polymorphisms with relevance to brain expression and metabolism 
TABLE 2: Single nucleotide polymorphisms (SNPs) in SNCA associated with Parkinson's disease.

\begin{tabular}{|c|c|c|c|}
\hline Variant & Region & Alleles & Studies* with significant association with PD risk \\
\hline REP1 & Promoter & $259 \mathrm{bp} / 261 \mathrm{bp} / 263 \mathrm{bp}$ & {$[47,50,60,64,65,68,71-73,75,77,79,81](\uparrow)[43,56,76](\downarrow)$} \\
\hline rs1372519 & Promoter & $\mathrm{A} / \mathrm{G}$ & {$[49](\downarrow)$} \\
\hline rs2301134 & Promoter & $\mathrm{C} / \mathrm{T}$ & {$[45,76](\uparrow)$} \\
\hline rs2301135 & Promoter & $\mathrm{C} / \mathrm{G}$ & {$[45](\downarrow)$} \\
\hline rs2619361 & Promoter & $\mathrm{A} / \mathrm{C}$ & {$[49](\uparrow)$} \\
\hline rs2619362 & $5^{\prime}$ region & $\mathrm{C} / \mathrm{T}$ & {$[49](\uparrow)$} \\
\hline rs2619363 & $5^{\prime}$ region & $\mathrm{G} / \mathrm{T}$ & {$[49,77](\uparrow)$} \\
\hline rs2619364 & $5^{\prime}$ region & $\mathrm{A} / \mathrm{G}$ & {$[66,77](\uparrow)$} \\
\hline rs 2583988 & $5^{\prime}$ region & $\mathrm{C} / \mathrm{T}$ & {$[49,56,61,77](\uparrow)$} \\
\hline rs2119787 & Intron & $\mathrm{A} / \mathrm{G}$ & {$[65](\downarrow)$} \\
\hline rs 2197120 & Intron & $\mathrm{A} / \mathrm{G}$ & {$[56](\downarrow)$} \\
\hline rs2572324 & Intron & $\mathrm{C} / \mathrm{T}$ & {$[49,60,64,65](\uparrow)$} \\
\hline rs2583959 & Intron & $\mathrm{C} / \mathrm{G}$ & {$[49,64](\uparrow)$} \\
\hline rs2736990 & Intron & $\mathrm{T} / \mathrm{C}$ & {$[27,28,41,47,49,52,55,60](\uparrow)[40](\downarrow)$} \\
\hline rs 2737020 & Intron & $\mathrm{C} / \mathrm{T}$ & {$[76](\downarrow)$} \\
\hline rs2737029 & Intron & $\mathrm{C} / \mathrm{T}$ & {$[56,65,80](\uparrow)$} \\
\hline rs 2737033 & Intron & $\mathrm{A} / \mathrm{G}$ & {$[46](\uparrow)$} \\
\hline rs356164 & Intron & $\mathrm{C} / \mathrm{G}$ & {$[76](\downarrow)$} \\
\hline rs356168 & Intron & $\mathrm{A} / \mathrm{G}$ & {$[64,80](\uparrow)$} \\
\hline rs356186 & Intron & $\mathrm{A} / \mathrm{G}$ & {$[56,60,76](\downarrow)$} \\
\hline rs356203 & Intron & $\mathrm{A} / \mathrm{G}$ & {$[27,80](\uparrow)$} \\
\hline rs356204 & Intron & $\mathrm{A} / \mathrm{G}$ & {$[80](\uparrow)$} \\
\hline rs3822086 & Intron & $\mathrm{C} / \mathrm{T}$ & {$[37](\downarrow)$} \\
\hline rs3857057 & Intron & $\mathrm{A} / \mathrm{G}$ & {$[33](\uparrow)$} \\
\hline rs3857059 & Intron & $\mathrm{A} / \mathrm{G}$ & {$[29,80](\uparrow)$} \\
\hline rs6848726 & Intron & $\mathrm{C} / \mathrm{T}$ & {$[80](\downarrow)$} \\
\hline rs7684318 & Intron & $\mathrm{C} / \mathrm{T}$ & {$[27,66](\uparrow)$} \\
\hline rs7689942 & Intron & $\mathrm{C} / \mathrm{T}$ & {$[33](\uparrow)$} \\
\hline rs894278 & Intron & $\mathrm{G} / \mathrm{T}$ & {$[35,36](\uparrow)$} \\
\hline rs1372520 & Intron & $\mathrm{C} / \mathrm{T}$ & {$[47,49](\uparrow)[60](\downarrow)$} \\
\hline rs10018362 & Intron & $\mathrm{C} / \mathrm{T}$ & {$[33](\uparrow)$} \\
\hline rs2737012 & Intron & $\mathrm{C} / \mathrm{T}$ & [49] $(\uparrow)$ \\
\hline rs3756063 & Intron & $\mathrm{C} / \mathrm{G}$ & {$[36](\uparrow)$} \\
\hline rs3775423 & Intron & $\mathrm{C} / \mathrm{T}$ & {$[48,60,64](\uparrow)$} \\
\hline rs356221 & $3^{\prime}$ region & $\mathrm{A} / \mathrm{T}$ & {$[45,48,77](\uparrow)$} \\
\hline rs356165 & $3^{\prime}$ region & $\mathrm{A} / \mathrm{G}$ & {$[28,50,51,54,69,73,76,77,80](\uparrow)$} \\
\hline rs356182 & $3^{\prime}$ region & $\mathrm{A} / \mathrm{G}$ & {$[32](\uparrow)$} \\
\hline rs356218 & $3^{\prime}$ region & $\mathrm{A} / \mathrm{G}$ & {$[47,49,60](\uparrow)$} \\
\hline rs356219 & $3^{\prime}$ region & $\mathrm{A} / \mathrm{G}$ & {$[28,42,44,46,52,53,59,61-63,65,73,78,80](\uparrow)$} \\
\hline rs 356220 & $3^{\prime}$ region & $\mathrm{C} / \mathrm{T}$ & {$[27,28,30,33,52,55,80](\uparrow)[40](\downarrow)$} \\
\hline rs 356225 & $3^{\prime}$ region & $\mathrm{C} / \mathrm{T}$ & {$[33](\uparrow)$} \\
\hline rs181489 & $3^{\prime}$ region & $\mathrm{C} / \mathrm{T}$ & {$[61,76,77](\uparrow)$} \\
\hline rs11931074 & $3^{\prime}$ region & $\mathrm{G} / \mathrm{T}$ & {$[30,31,34,39,55,57,61](\uparrow)[37,45](\downarrow)$} \\
\hline
\end{tabular}

SNP: single nucleotide polymorphism. *See Table 1. Arrows indicate whether the SNP increased $(\uparrow)$ or reduced ( $\downarrow$ ) PD susceptibility in each study, based on values of odds ratio and confidence intervals. 
TABLE 3: Association of environmental factors of PD with SNPs in SNCA.

\begin{tabular}{lcl}
\hline Environmental factors & Studies* & Results \\
\hline Smoking & {$[34,38,47,50,52,55,56,68,70]$} & $\begin{array}{l}\text { Individuals with GG-rs356219 and TT-rs356220 } \\
\text { genotypes [52] and carriers of allele REP1-263 bp [47] } \\
\text { who never had smoked had a significantly increased } \\
\text { risk of PD. }\end{array}$ \\
\hline Coffee intake & {$[38,47,55,56]$} & $\begin{array}{l}\text { No SNPs were significantly associated with this factor. } \\
\text { Pesticide exposure }\end{array}$ \\
\hline Alcohol drinking & {$[47,68,70,71]$} & $\begin{array}{l}\text { Chung et al. [47] found a suggestive association } \\
\text { between C-rs3775423 and pesticide exposure. }\end{array}$ \\
\hline Head injury & {$[38]$} & $\begin{array}{l}\text { Brighina et al. [75] found independent effects to alcohol } \\
\text { consumption and REP1-SNCA. Alcohol use was } \\
\text { associated with a decreased PD risk. }\end{array}$ \\
\hline
\end{tabular}

${ }^{*}$ See Table 1.

TABLE 4: Association of clinical aspects of PD and SNPs within SNCA.

\begin{tabular}{|c|c|c|}
\hline Variables & Studies ${ }^{*}$ & Results \\
\hline Age at onset & $\begin{array}{c}{[28,32,35,37,40,41,46,53,54,58,66} \\
69,70,72,79]\end{array}$ & $\begin{array}{l}\text { SNPs were associated with earlier PD onset: } \\
\text { REP1-263 bp [35, 69, 79]; C-rs2736990 [41]; G-rs894278 } \\
\text { [35]; G-rs356219 [46, 53, 58]; G-rs356215 [54] }\end{array}$ \\
\hline Motor outcomes ${ }^{\mathrm{a}}$ & {$[28,31,32,34,43,50,51,74]$} & $\begin{array}{l}\text { Wang et al. [31] found a protective association between } \\
\text { T-rs11931074 allele carriers and motor severity. Ritz et } \\
\text { al. [50] found that REP1- } 263 \text { bp and G-rs } 356165 \text { alleles } \\
\text { increased the risk of faster decline of motor function, } \\
\text { whereas Markopoulou et al. [43] demonstrated that } \\
\text { REP1-263 bp allele reduced the risk of developing motor } \\
\text { impairments }\end{array}$ \\
\hline Cognition outcomes ${ }^{\mathrm{b}}$ & {$[31-34,37,40,42,43,74,78]$} & $\begin{array}{l}\text { Markopoulou et al. [43] showed an increased risk of } \\
\text { cognitive impairment in carriers of REP1-259 bp allele. } \\
\text { Guella et al. [33] found a significant association of } \\
\text { C-rs10018362, T-rs7689942, and G-rs1348224 alleles } \\
\text { with PD with dementia }\end{array}$ \\
\hline Anxiety and depression $^{c}$ & {$[32,34,37,40,74]$} & No SNPs were significantly associated with symptoms \\
\hline $\begin{array}{l}\text { Autonomic and sleep } \\
\text { disorders }{ }^{\mathrm{d}}\end{array}$ & {$[34,74]$} & No SNPs were significantly associated with symptoms \\
\hline Hyposmia & {$[34,74]$} & $\begin{array}{l}\text { In Chen et al's study [34], TT-rs11931074 genotype } \\
\text { increased the risk of hyposmia in PD }\end{array}$ \\
\hline
\end{tabular}

${ }^{*}$ See Table 1. ${ }^{a}$ Questionnaires used: Unified Parkinson Disease Rating Scale-III and Hoehn and Yahr. ${ }^{b}$ Questionnaires used: Mini-Mental State Examination, Frontal Assessment Battery, Montreal Cognitive Assessment, Scales for Outcomes in Parkinson's Disease Cognition, Hopkins Verbal Learning Test-Revised, Letter-Number Sequencing Test and Trail Making Test, Semantic and Phonemic Verbal Fluency Tests, and Benton Judgment of Line Orientation test. ${ }^{c}$ Questionnaires used: Hamilton Rating Scale for Depression and Anxiety and Beck Depression Inventory. ${ }^{\mathrm{d}}$ Questionnaires used: REM Sleep Behavior Disorder Questionnaire, and Scales for Outcomes in Parkinson's Disease Autonomic, Nighttime Sleep, Daytime Sleepiness and Psychiatric Complications.

of substances contained in tobacco smoke and confirmed significant interactions of SNPs in cytochrome P-450 enzyme family genes (GSTM1, GSTP1, and NAT2). However, there is no information about the mechanisms that explain the biological interaction between SNCA genotypes and cigarette smoking.

\section{SNCA SNPs and PD Clinical Outcomes Interactions}

The influence of polymorphisms on PD phenotypic variability remains unclear. Indeed, few studies specifically investigated their associations with particular aspects of the disease, such as disease history and clinical outcomes (Table 4).
The age at onset is the most frequently investigated and well established aspect of disease history. Polymorphisms located in the promoter (REP1), introns (rs2736990, rs894278), and $3^{\prime}$ region (rs356219 and rs356165) are suggested to be predictors of earlier PD onset in Australian and Chinese [35], Spanish [54], German [46], and UK [61] samples. The identification of genetic features associated with the onset of PD has a relevant potential for therapeutic targeting. In view of the fact that neurodegeneration precedes the appearance of motor symptoms [102], it is critical to predict the risk of developing PD prior to clinical manifestations.

Even though it is expected that SNCA variants would influence individual traits or phenotypes of sporadic PD, this association was poorly explored in the studies. In a 
TABLE 5: Interactions between alpha-synuclein levels and SNCA SNPs.

\begin{tabular}{|c|c|c|c|}
\hline Study & SNP & Risk allele & Results \\
\hline \multirow{2}{*}{ Hu et al. [57] } & rs11931074 & $\mathrm{T}$ & $\begin{array}{l}\text { The allele was associated with reduced levels of alpha-synuclein in } \\
\text { serum }\end{array}$ \\
\hline & REP1 & & $\begin{array}{l}\text { Different alleles and genotypes did not influence levels of } \\
\text { alpha-synuclein in serum }\end{array}$ \\
\hline Mata et al. [65] & rs356219 & $\mathrm{C}$ & $\begin{array}{l}\text { CC genotype was correlated with increased levels of alpha-synuclein } \\
\text { in plasma }\end{array}$ \\
\hline \multirow{3}{*}{ Fuchs et al. $[84]^{\mathrm{a}}$} & rs2583988 & $\mathrm{T}$ & No correlation with alpha-synuclein mRNA or protein levels \\
\hline & REP1 & $261 \mathrm{pb}$ & $\begin{array}{l}256 \mathrm{pb} / 256 \mathrm{bp} \text { genotype was associated with lower alpha-synuclein } \\
\text { levels assessed in blood samples; no effect in brain samples }\end{array}$ \\
\hline & rs356219 & $\mathrm{C}$ & $\begin{array}{l}\text { CT genotype correlated with higher SNCA mRNA levels in the } \\
\text { substantia nigra and TT genotype showed higher SNCA mRNA levels } \\
\text { in the cerebellum; no effect in blood samples }\end{array}$ \\
\hline \multirow{3}{*}{ McCarthy et al. [24] ${ }^{\mathrm{a}}$} & rs 2736990 & G & \multirow{3}{*}{$\begin{array}{l}\text { In the } 3 \text { SNPs, the GG genotype correlated with an increased } \\
\text { expression ratio of SNCA112 mRNA in the frontal cortex }\end{array}$} \\
\hline & rs356165 & G & \\
\hline & rs356219 & G & \\
\hline \multirow{2}{*}{ McCarthy et al. [24] ${ }^{\mathrm{a}}$} & rs3857059 & G & \multirow{2}{*}{$\begin{array}{l}\text { No correlation between genotypes and the ratio expression levels of } \\
\text { SNCA11 } 2 \text { mRNA }\end{array}$} \\
\hline & rs17016074 & A & \\
\hline \multirow{2}{*}{ Cardo et al. [39] ${ }^{\mathrm{a}}$} & rs356165 & G & \multirow{2}{*}{$\begin{array}{l}\text { No significant differences for the SNCA isoform levels between the } \\
\text { different genotypes assessed in brain tissues }\end{array}$} \\
\hline & rs11931074 & $\mathrm{T}$ & \\
\hline
\end{tabular}

${ }^{\mathrm{a}}$ Postmortem studies.

longitudinal study with a North American sample, Ritz et al. [50] showed that the REP1-263 bp promoter variant and the G-rs356165 allele are risk factors to faster motor progression in Caucasian and non-Caucasian PD patients (OR 1.66; 95\% CI: 0.96-2.88). Wang et al. [31] found a protective association between T-rs11931074 allele and motor severity. However, in a larger sample of Caucasian patients, Markopoulou et al. [43] showed that REP1-263 pb allele reduced the risk of developing motor impairments. This divergence can be a result of differences in the methods of motor evaluation. According to Markopoulou et al. [43], the discrepancies may also suggest a dual and time-dependent role of SNCA.

Impairments in the olfactory function are a common early-stage nonmotor feature of PD, and the TT-rs11931074 genotype may increase the risk of hyposmia in PD cases [34].

Few other studies pointed out weak or absent associations with clinical outcomes such as anxiety or depression [32, $34,37,40,74]$, sleep and autonomic disorders [34, 74], and cognitive impairments [31, 32, 34, 37, 40, 74]. Regarding cognitive features, Markopoulou et al. [43] demonstrated that the REP1-259 pb allele increased the risk of cognitive outcomes. Trotta et al. [56] found significant associations of C-rs10018362, T-rs7689942, and G-rs1348224 alleles with PD with dementia and also identified a specific haplotype in intron 4 of SNCA (C-rs62306323 and T-rs7689942) associated with increased risk of PD with dementia. It is important to mention that limited data of SNP associations with PD phenotype in cross-sectional studies might be related to a single event of clinical assessment, which could mask possible effects. Studies of such associations could provide important clinical applicability of the significant findings of genotyping studies. More studies evaluating specific clinical aspects, especially with longitudinal designs, are necessary to enhance the understanding of how genetic factors contribute to PD.

\section{Biological Effects of SNCA SNPs}

There is increasing evidence supporting the biological effects of genetic variants in SNCA, possibly by modifying alphasynuclein expression. Among the studies listed in Table 5, the associations of SNCA-REP1 and $3^{\prime}$ variants (rs356219 and 11931074) and peripheral alpha-synuclein levels were investigated in Chinese [57] and North American [65] populations. Mata et al. [65] found an association of CC-356219 genotype with increased plasma levels of alpha-synuclein. A variation in the REP1 region might affect transcriptional activity by increasing the expression of alpha-synuclein and consequent protein accumulation [22, 23]. SNCA duplication and triplication in familial PD have been linked to increased mRNA expression levels [103] and to disease severity $[19,20]$.

In postmortem brain tissue studies, the $3^{\prime}$ region SNPs rs356219 [84], rs356165 [24], and rs11931074 [39] have been associated with increased gene expression. For rs356219, the heterozygote CT genotype correlated with higher levels of SNCA-mRNA in the substantia nigra of PD patients. However, the TT protective genotype was accompanied by higher expression in the cerebellum, a structure that is more preserved in the course of PD [84]. Similarly, G-rs356219 allele carriers presented higher levels of the SNCA112-mRNA isoform in the frontal cortex [24]. Further, PD patients presented higher levels of the SNCA-112 and SNCA-98 transcripts in the cerebellum and occipital cortex when compared to controls [39].

Linnertz et al. [104] investigated the effects of SNCA SNPs in $5^{\prime}$ and $3^{\prime}$ regions on SNCA expression in postmortem brains from neurologically normal subjects. For REP1, the $256 \mathrm{bp} / 256$ bp genotype correlated with lower SNCA-mRNA levels, corroborating the hypotheses that decreased SNCA levels protect against the disease. Unexpectedly, the protective 
genotypes AA-rs356219 and AA-rs365165 in the $3^{\prime}$ region correlated with higher levels of SNCA-mRNA in the temporal cortex and substantia nigra, which highlights an expanded regulatory effect of this region on total SNCA-mRNA levels.

Regarding in vivo studies, patients with SNP rs2583988 genotypes did not present alterations in alpha-synuclein levels in peripheral blood mononuclear cells, while the protein levels were reduced in the absence of the REP1 risk allele [84]. For SNPs in the $3^{\prime}$ region, while carriers of T-rs11931074 allele presented reduced levels of protein in serum [57], a higher level of alpha-synuclein in plasma was observed in carriers of the C-rs356219 allele [65].

\section{Genetical Background, Ethnicity, and the Effect of SNCA SNPs}

Methodological aspects such as variations in the sample size, control of population stratification, and statistical analyses can explain the discrepancies in the effects of SNPs among the different studies. In addition, it is common to exclude the influence of confounder variables as sex, age, and ethnic background, which can modify the results substantially.

The majority of the studies were carried out in countries of Europe, North America, and Asia, that is, populations with mainly Caucasian and Asian genetic backgrounds. Despite the fact that ethnic differences can preclude the generalization of the results in genetic studies, many of the SNPs showed similar effects in groups with different genetic backgrounds. For example, the SNP rs356219 remained an important risk factor for PD in studies performed within North American [65], Spanish [63], Russian [44], and Chinese [41] populations. Nevertheless, given the significance of results and perspectives of clinical advancement, it seems necessary to extend these investigations to other continents, in order to confirm whether these genetic effects are consistent across different populations and to verify the implications of between-population heterogeneity.

Finally, apart from variants in the SNCA gene, it is necessary to consider the role of interactions between multiple genetic variants in disease risk and clinical profile. For example, investigations of phenotypic diversity in PD have identified an association between SNCA and MAPT. This association contributed to increased cognitive and motor severity in a Chinese sample [31] and influenced the development of cognitive impairment and dementia in a British sample [78]. In addition, polymorphisms in GAB [28] and LRRK2 [58] have been associated with earlier age at the onset in a European-American population and in a Spanish sample, respectively. Also, in North Americans, APOE variants predicted lower cognitive performance in PD patients [42].

\section{Conclusions}

This review collected the contributions of polymorphisms in the SNCA gene to PD susceptibility and clinical phenotypes. In most of the studies, the influence of polymorphisms in multiple regions of SNCA gene was pointed out, such as the promoter region (REP1-SNCA), 3' end (e.g., rs11931074 and rs356219), $3^{\prime}$ untranslated regions (e.g., rs356165), and introns (e.g., rs7684318, rs894278, and rs276990). In addition, we highlight that it is necessary to expand the clinical applicability of these data, as well as investigate the role of SNCA variations in populations with different ethnic backgrounds.

\section{Conflicts of Interest}

The authors declare that they have no conflicts of interest.

\section{Acknowledgments}

The authors would like to thank the funding agencies Conselho Nacional de Desenvolvimento Científico e Tecnológico (CNPq) (Grant no. 402054/2010-5), Coordenação de Aperfeiçoamento de Pessoal de Nível Superior (CAPES), Fundação de Apoio à Pesquisa do Estado do Rio Grande do Norte (FAPERN/PRONEX), and Fundação de Amparo à Pesquisa do Estado de São Paulo (FAPESP) (Grant no. 2015/12308-5).

\section{References}

[1] S. Fahn, "Description of Parkinson's disease as a clinical syndrome," Annals of the New York Academy of Sciences, vol. 991, pp. 1-14, 2003.

[2] K. Wirdefeldt, H. Adami, P. Cole, D. Trichopoulos, and J. Mandel, "Epidemiology and etiology of Parkinson's disease: a review of the evidence," European Journal of Epidemiology, vol. 26, no. 1, supplement, pp. S1-S58, 2011.

[3] L. M. de Lau and M. M. Breteler, "Epidemiology of Parkinson's disease," The Lancet Neurology, vol. 5, no. 6, pp. 525-535, 2006.

[4] W. Satake, Y. Nakabayashi, I. Mizuta et al., "Genome-wide association study identifies common variants at four loci as genetic risk factors for Parkinson's disease," Nature Genetics, vol. 41, no. 12, pp. 1303-1307, 2009.

[5] J. Simón-Sánchez, C. Schulte, J. M. Bras, M. Sharma, D. Gibbs Berg Jr. et al., "Genome-wide association study reveals genetic risk underlying Parkinsons disease," Nature Genetics, vol. 41, pp. 1308-1312, 2009.

[6] M. Sharma, J. P. A. Ioannidis, J. O. Aasly et al., "Large-scale replication and heterogeneity in Parkinson disease genetic loci," Neurology, vol. 79, no. 7, pp. 659-667, 2012.

[7] H. A. Lashuel, C. R. Overk, A. Oueslati, and E. Masliah, "The many faces of $\alpha$-synuclein: from structure and toxicity to therapeutic target," Nature Reviews Neuroscience, vol. 14, no. 1, pp. 38-48, 2013.

[8] J. Bendor, T. Logan, and R. Edwards, "The function of $\alpha$ synuclein," Neuron, vol. 79, no. 6, pp. 1044-1066, 2013.

[9] S. E. Eisbach and T. F. Outeiro, "Alpha-Synuclein and intracellular trafficking: Impact on the spreading of Parkinson's disease pathology," Journal of Molecular Medicine, vol. 91, no. 6, pp. 693$703,2013$.

[10] J. Q. Trojanowski and V. M.-Y. Lee, "Aggregation of neurofilament and $\alpha$-synuclein proteins in Lewy bodies: implications for the pathogenesis of Parkinson disease and Lewy body dementia," Archives of Neurology, vol. 55, no. 2, pp. 151-152, 1998. 
[11] M. G. Spillantini, M. L. Schmidt, V. M. Lee, J. Q. Trojanowski, R. Jakes, and M. Goedert, " $\alpha$-synuclein in Lewy bodies," Nature, vol. 388 , no. 6645 , pp. 839-840, 1997.

[12] M. G. Spillantini, R. A. Crowther, R. Jakes, M. Hasegawa, and M. Goedert, " $\alpha$-Synuclein in filamentous inclusions of Lewy bodies from Parkinson's disease and dementia with Lewy bodies," Proceedings of the National Academy of Sciences of the United States of America, vol. 95, no. 11, pp. 6469-6473, 1998.

[13] O. Khalaf, B. Fauvet, A. Oueslati et al., "The H50Q mutation enhances $\alpha \alpha$-synuclein aggregation, secretion, and toxicity," Journal of Biological Chemistry, vol. 289, no. 32, pp. 21856-21876, 2014.

[14] M. Bozi, D. Papadimitriou, R. Antonellou et al., "Genetic assessment of familial and early-onset Parkinson's disease in a Greek population," European Journal of Neurology, vol. 21, no. 7, pp. 963-968, 2014.

[15] R. Krüger, W. Kuhn, T. Müller et al., "Ala30Pro mutation in the gene encoding $\alpha$-synuclein in Parkinson's disease," Nature Genetics, vol. 18, no. 2, pp. 106-108, 1998.

[16] M. H. Polymeropoulos, C. Lavedan, E. Leroy et al., "Mutation in the $\alpha$-synuclein gene identified in families with Parkinson's disease," Science, vol. 276, no. 5321, pp. 2045-2047, 1997.

[17] J. J. Zarranz, J. Alegre, J. C. Gómez-Esteban et al., “The new mutation, E46K, of $\alpha$-synuclein causes Parkinson and Lewy body dementia," Annals of Neurology, vol. 55, no. 2, pp. 164-173, 2004.

[18] D. Hoffman-Zacharska, D. Koziorowski, O. A. Ross et al., "Novel A18T and pA29S substitutions in $\alpha$-synuclein may be associated with sporadic Parkinson's disease," Parkinsonism and Related Disorders, vol. 19, no. 11, pp. 1057-1060, 2013.

[19] P. Ibáñez, A.-M. Bonnet, B. Débarges et al., "Causal relation between $\alpha$-synuclein gene duplication and familial Parkinson's disease," The Lancet, vol. 364, no. 9440, pp. 1169-1171, 2004.

[20] M. Chartier-Harlin, J. Kachergus, C. Roumier et al., " $\alpha$ synuclein locus duplication as a cause of familial Parkinson's disease," The Lancet, vol. 364, no. 9440, pp. 1167-1169, 2004.

[21] P. Pals, S. Lincoln, J. Manning et al., " $\alpha$-Synuclein promoter confers susceptibility to Parkinson's disease," Annals of Neurology, vol. 56, no. 4, pp. 591-595, 2004.

[22] O. Chiba-Falek and R. L. Nussbaum, "Effect of allelic variation at the NACP-Rep1 repeat upstream of the $\alpha$-synuclein gene (SNCA) on transcription in a cell culture luciferase reporter system," Human Molecular Genetics, vol. 10, no. 26, pp. 31013109, 2001.

[23] O. Chib-Falek, J. W. Touchman, and R. L. Nussbaum, "Functional analysis of intra-allelic variation at NACP-Repl in the $\alpha$ synuclein gene," Human Genetics, vol. 113, no. 5, pp. 426-431, 2003.

[24] J. J. McCarthy, C. Linnertz, L. Saucier et al., "The effect of SNCA 3/ region on the levels of SNCA-112 splicing variant," Neurogenetics, vol. 12, no. 1, pp. 59-64, 2011.

[25] S. Sotiriou, G. Gibney, A. D. Baxevanis, and R. L. Nussbaum, "A single nucleotide polymorphism in the 3/UTR of the SNCA gene encoding alpha-synuclein is a new potential susceptibility locus for Parkinson disease," Neuroscience Letters, vol. 461, no. 2, pp. 196-201, 2009.

[26] G. Wang, J. M. van der Walt, G. Mayhew et al., "Variation in the miRNA-433 binding site of FGF20 confers risk for Parkinson disease by overexpression of $\alpha$-synuclein," The American Journal of Human Genetics, vol. 82, no. 2, pp. 283-289, 2008.
[27] D. J. Davila-Ortiz de Montellano, M. Rodriguez-Violante, A. Fresan, N. Monroy-Jaramillo, and P. Yescas-Gomez, "Frequency of single nucleotide polymorphisms and alpha-synuclein haplotypes associated with sporadic Parkinsons disease in the Mexican population," Revue Neurologique, vol. 63, pp. 345-350, 2016.

[28] A. A. Davis, K. M. Andruska, B. A. Benitez, B. A. Racette, J. S. Perlmutter, and C. Cruchaga, "Variants in GBA, SNCA, and MAPT influence Parkinson disease risk, age at onset, and progression," Neurobiology of Aging, vol. 37, pp. 209.el-209.e7, 2016.

[29] S. García, G. Chavira-Hernández, M. Gallegos-Arreola et al., "The rs3857059 variant of the SNCA gene is associated with Parkinson's disease in Mexican Mestizos," Arquivos de NeuroPsiquiatria, vol. 74, no. 6, pp. 445-449, 2016.

[30] N. Shahmohammadibeni, S. Rahimi-Aliabadi, J. Jamshidi et al., "The analysis of association between SNCA, HUSEYO and CSMD1 gene variants and Parkinson's disease in Iranian population," Neurological Sciences, vol. 37, no. 5, pp. 731-736, 2016.

[31] G. Wang, Y. Huang, Wei Chen et al., "Variants in the SNCA gene associate with motor progression while variants in the MAPT gene associate with the severity of Parkinson's disease," Parkinsonism and Related Disorders, vol. 24, pp. 89-94, 2016.

[32] L. Cheng, L. Wang, N.-N. Li et al., "SNCA rs356182 variant increases risk of sporadic Parkinson's disease in ethnic Chinese," Journal of the Neurological Sciences, vol. 368, pp. 231-234, 2016.

[33] I. Guella, D. M. Evans, C. Szu-Tu et al., " $\alpha$-synuclein genetic variability: a biomarker for dementia in Parkinson disease," Annals of Neurology, vol. 79, no. 6, pp. 991-999, 2016.

[34] W. Chen, W.-Y. Kang, S. Chen et al., "Hyposmia correlates with SNCA variant and non-motor symptoms in Chinese patients with Parkinson's disease," Parkinsonism and Related Disorders, vol. 21, no. 6, pp. 610-614, 2015.

[35] Y. Huang, G. Wang, D. Rowe et al., "SNCA gene, but not MAPT, influences onset age of Parkinson's disease in Chinese and Australians," BioMed Research International, vol. 2015, Article ID 135674, 2015.

[36] W. Han, Y. Liu, Y. Mi, J. Zhao, D. Liu, and Q. Tian, "Alphasynuclein (SNCA) polymorphisms and susceptibility to Parkinson's disease: a meta-analysis," American Journal of Medical Genetics, Part B: Neuropsychiatric Genetics, vol. 168, no. 2, pp. 123-134, 2015.

[37] Y. P. Chen, Q.-Q. Wei, R. W. Ou et al., "Genetic variants of snca are associated with susceptibility to Parkinson's disease but not amyotrophic lateral sclerosis or multiple system atrophy in a Chinese population," PLOS ONE, vol. 10, no. 7, Article ID e0133776, 2015.

[38] J. Gao, R. Liu, E. Zhao et al., "Head injury, potential interaction with genes, and risk for Parkinson's disease," Parkinsonism and Related Disorders, vol. 21, no. 3, pp. 292-296, 2015.

[39] L. F. Cardo, E. Coto, L. de Mena et al., "Alpha-synuclein transcript isoforms in three different brain regions from Parkinson's disease and healthy subjects in relation to the SNCA rs356165/rs11931074 polymorphisms," Neuroscience Letters, vol. 562, pp. 45-49, 2014.

[40] X. Y. Guo, Y. P. Chen, W. Song et al., "SNCA variants rs2736990 and rs356220 as risk factors for Parkinson's disease but not for amyotrophic lateral sclerosis and multiple system atrophy in a Chinese population," Neurobiology of Aging, vol. 35, no. 12, pp. 2882.e1-2882.e6, 2014. 
[41] F. Pan, H. Ding, H. Dong et al., "Association of polymorphism in rs2736990 of the -synuclein gene with Parkinson/s disease in a Chinese population," Neurology India, vol. 61, no. 4, pp. 360364, 2013.

[42] I. F. Mata, J. B. Leverenz, D. Weintraub et al., "APOE, MAPT, and SNCA genes and cognitive performance in Parkinson disease," JAMA Neurology, vol. 71, no. 11, pp. 1405-1412, 2014.

[43] K. Markopoulou, J. M. Biernacka, S. M. Armasu et al., "Does $\alpha$-synuclein have a dual and opposing effect in preclinical vs. clinical Parkinson's disease?" Parkinsonism and Related Disorders, vol. 20, no. 6, pp. 584-589, 2014.

[44] A. Emelyanov, P. Andoskin, A. Yakimovskii et al., "SNCA, LRRK2, MAPT polymorphisms and Parkinson's disease in Russia," Parkinsonism and Related Disorders, vol. 19, no. 11, pp. 1064-1065, 2013.

[45] Y.-H. Wu-Chou, Y.-T. Chen, T.-H. Yeh et al., "Genetic variants of SNCA and LRRK2 genes are associated with sporadic PD susceptibility: a replication study in a Taiwanese cohort," Parkinsonism and Related Disorders, vol. 19, no. 2, pp. 251-255, 2013.

[46] K. Brockmann, C. Schulte, A.-K. Hauser et al., "SNCA: major genetic modifier of age at onset of Parkinson's disease," Movement Disorders, vol. 28, no. 9, pp. 1217-1221, 2013.

[47] S. J. Chung, S. M. Armasu, K. J. Anderson et al., "Genetic susceptibility loci, environmental exposures, and Parkinson's disease: a case-control study of gene-environment interactions," Parkinsonism and Related Disorders, vol. 19, no. 6, pp. 595-599, 2013.

[48] L. Pihlstrøm, G. Axelsson, K. A. Bjørnarå et al., "Supportive evidence for 11 loci from genome-wide association studies in Parkinson's disease," Neurobiology of Aging, vol. 34, no. 6, pp. 1708.e7-1708.e13, 2013.

[49] M. G. Heckman, A. I. Soto-Ortolaza, N. N. Diehl et al., "Evaluation of the role of SNCA variants in survival without neurological disease," PLoS ONE, vol. 7, no. 8, Article ID e42877, 2012.

[50] B. Ritz, S. L. Rhodes, Y. Bordelon, and J. Bronstein, “ $\alpha$-Synuclein genetic variants predict faster motor symptom progression in idiopathic Parkinson disease," PLoS ONE, vol. 7, no. 5, Article ID e36199, 2012.

[51] I. Schmitt, U. Wüllner, J. P. Van Rooyen et al., "Variants in the 3/UTR of SNCA do not affect miRNA-433 binding and alphasynuclein expression," European Journal of Human Genetics, vol. 20, no. 12, pp. 1265-1269, 2012.

[52] Y. Miyake, K. Tanaka, W. Fukushima et al., "SNCA polymorphisms, smoking, and sporadic Parkinson's disease in Japanese," Parkinsonism and Related Disorders, vol. 18, no. 5, pp. 557-561, 2012.

[53] F. Pan, H. Dong, H. Ding et al., "SNP rs356219 of the $\alpha$-synuclein (SNCA) gene is associated with Parkinson's disease in a Chinese Han population," Parkinsonism and Related Disorders, vol. 18, no. 5, pp. 632-634, 2012.

[54] L. F. Cardo, E. Coto, L. de Mena et al., "A search for SNCA 3/ UTR variants identified SNP rs356165 as a determinant of disease risk and onset age in Parkinson's disease," Journal of Molecular Neuroscience, vol. 47, no. 3, pp. 425-430, 2012.

[55] J. Gao, M. A. Nalls, M. Shi et al., "An exploratory analysis on gene-environment interactions for Parkinson disease," Neurobiology of Aging, vol. 33, no. 10, pp. 2528.el-2528.e6, 2012.

[56] L. Trotta, I. Guella, G. Soldà et al., "SNCA and MAPT genes: independent and joint effects in Parkinson disease in the Italian population," Parkinsonism and Related Disorders, vol. 18, no. 3, pp. 257-262, 2012.

[57] Y. Hu, B. Tang, J. Guo et al., "Variant in the 30 region of SNCA associated with Parkinson's disease and serum $\alpha$-synuclein levels," Journal of Neurology, vol. 259, no. 3, pp. 497-504, 2012.

[58] T. Botta-Orfila, M. Ezquerra, P. Pastor et al., "Age at onset in LRRK2-associated PD is modified by SNCA variants," Journal of Molecular Neuroscience, vol. 48, no. 1, pp. 245-247, 2012.

[59] I. F. Mata, D. Yearout, V. Alvarez et al., "Replication of MAPT and SNCA, but not PARK16-18, as susceptibility genes for Parkinson's disease," Movement Disorders, vol. 26, no. 5, pp. 819823, 2011.

[60] S. J. Chung, S. M. Armasu, J. M. Biernacka et al., "Common variants in PARK loci and related genes and Parkinson's disease," Movement Disorders, vol. 26, no. 2, pp. 280-288, 2011.

[61] A. Elbaz, O. A. Ross, J. P. A. Ioannidis et al., "Independent and joint effects of the MAPT and SNCA genes in Parkinson disease," Annals of Neurology, vol. 69, no. 5, pp. 778-792, 2011.

[62] C. Wider, C. Vilariño-Güell, M. G. Heckman et al., "SNCA, MAPT, and GSK3B in Parkinson disease: A gene-gene interaction study," European Journal of Neurology, vol. 18, no. 6, pp. 876-881, 2011.

[63] T. Botta-Orfila, M. Ezquerra, J. Ríos et al., "Lack of interaction of SNCA and MAPT genotypes in Parkinson's disease," European Journal of Neurology, vol. 18, no. 3, p. e32, 2011.

[64] J. M. Biernacka, S. M. Armasu, J. M. Cunningham, J. Eric Ahlskog, S. J. Chung, and D. M. Maraganore, "Do interactions between SNCA, MAPT, and LRRK2 genes contribute to Parkinson's disease susceptibility?" Parkinsonism and Related Disorders, vol. 17, no. 10, pp. 730-736, 2011.

[65] I. F. Mata, M. Shi, P. Agarwal et al., "SNCA variant associated with Parkinson disease and plasma $\alpha$-synuclein level," Archives of Neurology, vol. 67, no. 11, pp. 1350-1356, 2010.

[66] L. Yu, P. Xu, X. He et al., "SNP rs7684318 of the $\alpha$-synuclein gene is associated with Parkinson's disease in the Han Chinese population," Brain Research, vol. 1346, pp. 262-265, 2010.

[67] F.-Y. Hu, W.-B. Hu, L. Liu et al., "Lack of replication of a previously reported association between polymorphism in the 3'UTR of the alpha-synuclein gene and Parkinson's disease in Chinese subjects," Neuroscience Letters, vol. 479, no. 1, pp. 3133, 2010.

[68] N. M. Gatto, S. L. Rhodes, A. D. Manthripragada et al., "Alphasynuclein gene may interact with environmental factors in increasing risk of Parkinson's disease," Neuroepidemiology, vol. 35, no. 3, pp. 191-195, 2010.

[69] A. Rajput, C. Vilariño-Güell, M. L. Rajput et al., "Alphasynuclein polymorphisms are associated with Parkinson's disease in a Saskatchewan population," Movement Disorders, vol. 24, no. 16, pp. 2411-2414, 2009.

[70] G. T. Sutherland, G. M. Halliday, P. A. Silburn et al., "Do polymorphisms in the familial parkinsonism genes contribute to risk for sporadic Parkinson's disease?" Movement Disorders, vol. 24, no. 6, pp. 833-838, 2009.

[71] L. Brighina, N. K. Schneider, T. G. Lesnick et al., " $\alpha$-Synuclein, alcohol use disorders, and Parkinson disease: a case-control study," Parkinsonism and Related Disorders, vol. 15, no. 6, pp. 430-434, 2009.

[72] D. M. Kay, S. A. Factor, A. Samii et al., "Genetic association between $\alpha$-synuclein and idiopathic Parkinson's disease," American Journal of Medical Genetics, Part B: Neuropsychiatric Genetics, vol. 147, no. 7, pp. 1222-1230, 2008. 
[73] R. Myhre, M. Toft, J. Kachergus et al., "Multiple alpha-synuclein gene polymorphisms are associated with Parkinson's disease in a Norwegian population," Acta Neurologica Scandinavica, vol. 118, no. 5, pp. 320-327, 2008.

[74] D. Verbaan, S. Boesveldt, S. M. van Rooden et al., "Is olfactory impairment in Parkinson disease related to phenotypic or genotypic characteristics?" Neurology, vol. 71, no. 23, pp. 18771882, 2008.

[75] L. Brighina, R. Frigerio, N. K. Schneider et al., " $\alpha$-Synuclein, pesticides, and Parkinson disease: a case-control study," Neurology, vol. 70, no. 16, pp. 1461-1469, 2008.

[76] O. A. Ross, D. Gosal, J. T. Stone et al., "Familial genes in sporadic disease: common variants of $\alpha$-synuclein gene associate with Parkinson's disease," Mechanisms of Ageing and Development, vol. 128, no. 5-6, pp. 378-382, 2007.

[77] S. Winkler, J. Hagenah, S. Lincoln et al., " $\alpha$-Synuclein and Parkinson disease susceptibility," Neurology, vol. 69, no. 18, pp. 1745-1750, 2007.

[78] A. Goris, C. H. Williams-Gray, G. R. Clark et al., "Tau and $\alpha$-synuclein in susceptibility to, and dementia in, Parkinson's disease," Annals of Neurology, vol. 62, no. 2, pp. 145-153, 2007.

[79] G. M. Hadjigeorgiou, G. Xiromerisiou, V. Gourbali et al., "Association of $\alpha$-synuclein Rep1 polymorphism and Parkinson's disease: Influence of Rep1 on age at onset," Movement Disorders, vol. 21, no. 4, pp. 534-539, 2006.

[80] J. C. Mueller, J. Fuchs, A. Hofer et al., "Multiple regions of $\alpha$ synuclein are associated with Parkinson's disease," Annals of Neurology, vol. 57, no. 4, pp. 535-541, 2005.

[81] C. E. Mamah, T. G. Lesnick, S. J. Lincoln et al., "Interaction of $\alpha$-synuclein and tau genotypes in Parkinson's disease," Annals of Neurology, vol. 57, no. 3, pp. 439-443, 2005.

[82] P. Spadafora, G. Annesi, A. A. Pasqua et al., "NACP-REP1 polymorphism is not involved in Parkinson's disease: a casecontrol study in a population sample from southern Italy," Neuroscience Letters, vol. 351, no. 2, pp. 75-78, 2003.

[83] Y. Izumi, H. Morino, M. Oda et al., "Genetic studies in Parkinson's disease with an $\alpha$-synuclein/NACP gene polymorphism in Japan," Neuroscience Letters, vol. 300, no. 2, pp. 125-127, 2001.

[84] J. Fuchs, A. Tichopad, Y. Golub et al., "Genetic variability in the SNCA gene influences $\alpha$-synuclein levels in the blood and brain," FASEB Journal, vol. 22, no. 5, pp. 1327-1334, 2008.

[85] M. A. Nalls, N. Pankratz, C. M. Lill et al., "Large-scale metaanalysis of genome-wide association data identifies six new risk loci for Parkinson's disease," Nature Genetics, vol. 46, no. 9, pp. 989-993, 2014.

[86] C. B. Do, J. Y. Tung, E. Dorfman et al., "Web-based genomewide association study identifies two novel loci and a substantial genetic component for parkinson's disease," PLoS Genetics, vol. 7, no. 6, Article ID e1002141, 2011.

[87] Z. Wang, H. Lei, M. Zheng, Y. Li, Y. Cui, and F. Hao, "Metaanalysis of the association between alzheimer disease and variants in GAB2, PICALM, and SORL1," Molecular Neurobiology, vol. 53, no. 9, pp. 6501-6510, 2016.

[88] E. K. Tan, H. K. Kwok, L. C. Tan, W. T. Zhao, K. M. Prakash, W. L. Au et al., "Analysis of GWAS-linked loci in Parkinson disease reaffirms PARK16 as a susceptibility locus," Neurology, vol. 75, pp. 508-512, 2010.

[89] S. Lesage and A. Brice, "Parkinson's disease: from monogenic forms to genetic susceptibility factors," Human Molecular Genetics, vol. 18, no. R1, pp. R48-R59, 2009.
[90] J. N. Foo, S. J. Chung, L. C. Tan et al., "Linking a genomewide association study signal to a LRRK2 coding variant in Parkinson's disease," Movement Disorders, vol. 31, no. 4, pp. 484487, 2016.

[91] D. M. Maraganore, M. de Andrade, A. Elbaz et al., "Collaborative analysis of $\alpha$-synuclein gene promoter variability and Parkinson disease," The Journal of the American Medical Association, vol. 296, no. 6, pp. 661-670, 2006.

[92] L. L. Venda, S. J. Cragg, V. L. Buchman, and R. Wade-Martins, " $\alpha$-Synuclein and dopamine at the crossroads of Parkinson's disease," Trends in Neurosciences, vol. 33, no. 12, pp. 559-568, 2010.

[93] J. A. Firestone, T. Smith-Weller, G. Franklin, P. Swanson, W. T. Longstreth Jr., and H. Checkoway, "Pesticides and risk of parkinson disease: a population-based case-control study," Archives of Neurology, vol. 62, no. 1, pp. 91-95, 2005.

[94] K. M. Semchuk, E. J. Love, and R. G. Lee, "Parkinson's disease and exposure to rural environmental factors: a population based case-control study," Journal Canadien des Sciences Neurologiques, vol. 18, no. 3, pp. 279-286, 1991.

[95] M. F. Allam, A. S. Del Castillo, and R. Fernández-Crehuet Navajas, "Parkinson's disease risk factors: genetic, environmental, or both?” Neurological Research, vol. 27, no. 2, pp. 206-208, 2005.

[96] M. F. Allam, M. J. Campbell, A. Hofman, A. S. Del Castillo, and R. F.-C. Navajas, "Smoking and Parkinson's disease: systematic review of prospective studies," Movement Disorders, vol. 19, no. 6, pp. 614-621, 2004.

[97] X. Li, W. Li, G. Liu, X. Shen, and Y. Tang, "Association between cigarette smoking and Parkinson's disease: a meta-analysis," Archives of Gerontology and Geriatrics, vol. 61, no. 3, pp. 510516, 2015.

[98] J. Costa, N. Lunet, C. Santos, J. Santos, and A. Vaz-Carneiro, "Caffeine exposure and the risk of Parkinson's disease: a systematic review and meta-analysis of observational studiess," Journal of Alzheimer's Disease, vol. 20, supplement 1, pp. S221-S238, 2010.

[99] S. S. Bettiol, T. C. Rose, C. J. Hughes, and L. A. Smith, "Alcohol consumption and Parkinson's disease risk: a review of recent findings," Journal of Parkinson's Disease, vol. 5, no. 3, pp. 425442, 2015.

[100] P. Riederer, C. Konradi, G. Hebenstreit, and M. Youdim, "Neurochemical perspectives to the function of monoamine oxidase," Acta Neurologica Scandinavica, vol. 80, pp. 41-45, 1989.

[101] G. S. Shahi and S. M. Moochhala, "Smoking and Parkinson's disease-a new perspective," Reviews on Environmental Health, vol. 9, no. 3, pp. 123-136, 1991.

[102] R. Savica, W. A. Rocca, and J. E. Ahlskog, "When does Parkinson disease start?" Archives of Neurology, vol. 67, no. 7, pp. 798-801, 2010.

[103] M. Farrer, J. Kachergus, L. Forno et al., "Comparison of kindreds with Parkinsonism and $\alpha$-synuclein genomic multiplications," Annals of Neurology, vol. 55, no. 2, pp. 174-179, 2004.

[104] C. Linnertz, L. Saucier, D. Ge et al., "Genetic regulation of $\alpha$ synuclein mRNA expression in various human brain tissues," PLoS ONE, vol. 4, no. 10, Article ID e7480, 2009. 


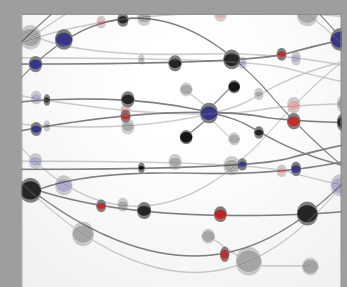

The Scientific World Journal
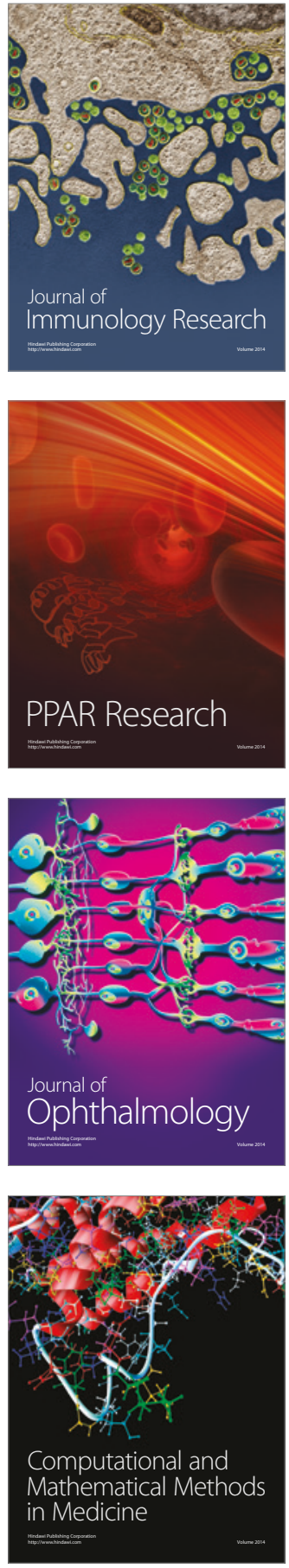

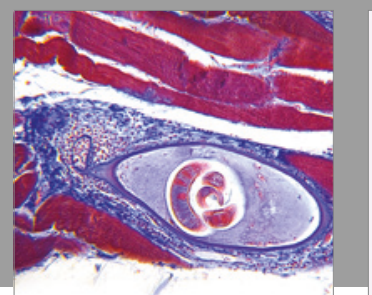

Gastroenterology Research and Practice
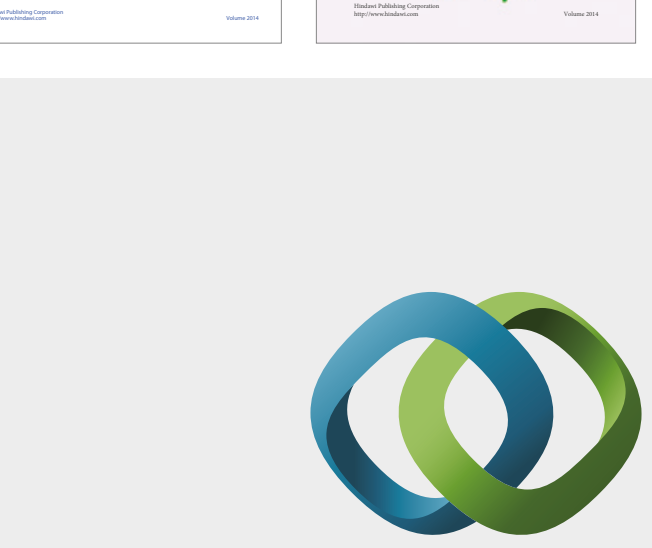

\section{Hindawi}

Submit your manuscripts at

https://www.hindawi.com
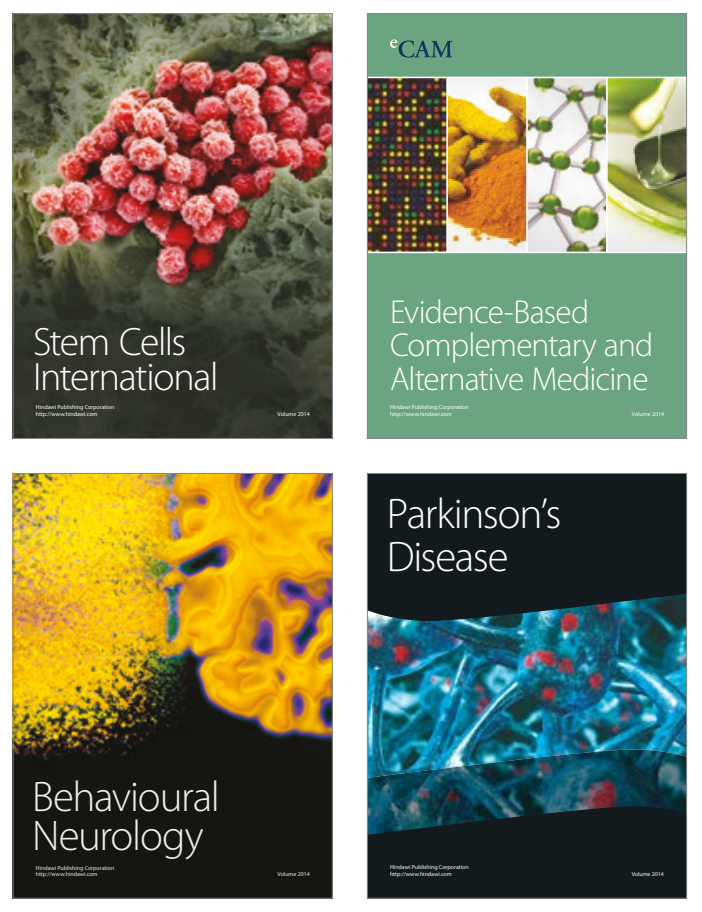
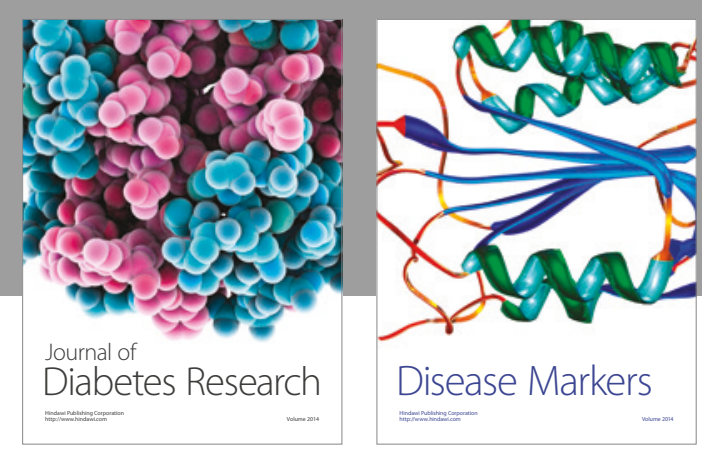

Disease Markers
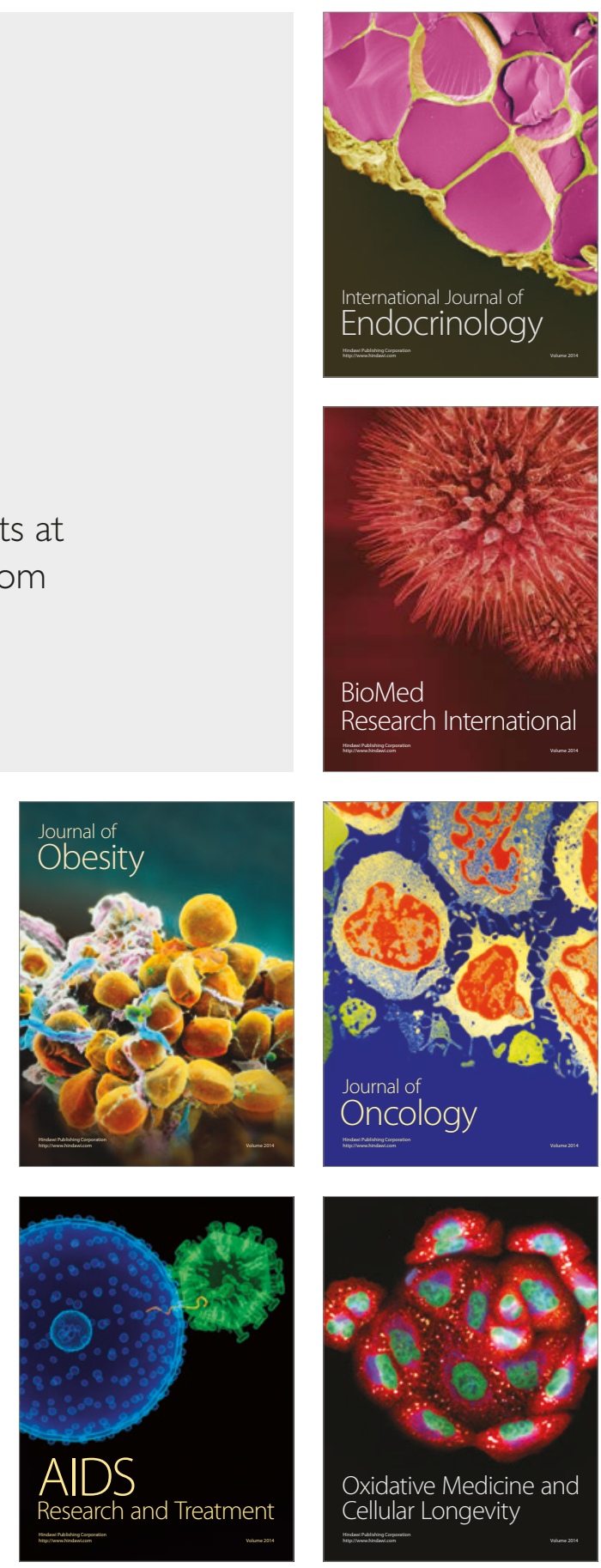